\title{
Myrmica Ants and Their Butterfly Parasites with Special Focus on the Acoustic Communication
}

\author{
F. Barbero, D. Patricelli, M. Witek, E. Balletto, L. P. Casacci, M. Sala, and S. Bonelli \\ Department of Animal and Human Biology, University of Turin, via Accademia Albertina 13, 10123 Turin, Italy \\ Correspondence should be addressed to S. Bonelli, simona.bonelli@unito.it
}

Received 30 September 2011; Accepted 18 December 2011

Academic Editor: Jean Paul Lachaud

Copyright () 2012 F. Barbero et al. This is an open access article distributed under the Creative Commons Attribution License, which permits unrestricted use, distribution, and reproduction in any medium, provided the original work is properly cited.

\begin{abstract}
About 10,000 arthropod species live as ants' social parasites and have evolved a number of mechanisms allowing them to penetrate and survive inside the ant nests. Myrmica colonies, in particular, are exploited by numerous social parasites, and the presence of their overwintering brood, as well as of their polygyny, contributes to make them more vulnerable to infestation. Butterflies of the genus Maculinea are among the most investigated Myrmica inquilines. These lycaenids are known for their very complex biological cycles. Maculinea species are obligated parasites that depend on a particular food plant and on a specific Myrmica species for their survival. Maculinea larvae are adopted by Myrmica ants, which are induced to take them into their nests by chemical mimicry. Then the parasite spends the following 11-23 months inside the ants' nest. Mimicking the acoustic emission of the queen ants, Maculinea parasites not only manage to become integrated, but attain highest rank within the colony. Here we review the biology of Maculinea/Myrmica system with a special focus on some recent breakthrough concerning their acoustical patterns.
\end{abstract}

\section{Butterflies and Ants}

Most myrmecophiles are commensals or mutualists, which live undisturbed or even actively protected within the foraging areas or territories of ants [1-3]. Their functional and evolutionary ecology, as well as their truly amazing diversity, have been reviewed by Wasmann [4], Donisthorpe [5], Hinton [6], Malicky [7], Hölldobler and Wilson [1], DeVries $[8,9]$, Fiedler $[10,11]$, Pierce et al. [12], and others.

The interactions that have evolved between insects and ants range from loose facultative associations to obligate dependency (as concerns butterflies, see $[3,11,13,14]$ ). The nests of eu-social arthropods, including insects such as ants, bees, wasps, or termites, are aggressively defended from predators and intruders alike. As a consequence, these nests provide very safe havens for any roughly ant-sized organism having evolved the necessary adaptations to penetrate them and to become accepted as "self" by the workers' caste $[4,5,15]$. Around 10,000-15,000 insect morphospecies have evolved as social parasites of ants, thus accounting for a significant proportion of the world's biodiversity. Yet, despite the many species, most ant social parasites are exceedingly rare or localized, in comparison to the abundance and distribution not only of their ant hosts but also of other symbionts, which loosely interact with ants $[1,16,17]$.

Myrmecophily is widespread among Lepidoptera, most particularly as concerns the Riodinidae and Lycaenidae [9, 12], which are often globally referred to as "lycaenoids" [10], and which make up approximately $30 \%$ of all known Papilionoidea [18]. Their relationships with ants can be mutualistic or parasitic and vary from facultative to strictly obligate. In the case of facultative myrmecophiles, the survival of butterfly larvae does not depend on the presence of attendant ants, and associations are unspecific. In other words, these lycaenoids can use ants belonging to several different species, or even subfamilies $[11,12]$. On the contrary, in obligate ant associations, butterfly immatures are dependent on ants' presence, at least in some part of their life cycle and interactions are much more species specific $[11,12]$.

Achieving a myrmecophilous life style requires evolving numerous special adaptations, which are necessary for avoiding ant aggression and for communicating with ants. The cuticle of many myrmecophilous butterfly larvae is thicker than in other groups of Papilionoidea and the head can be retracted under a sclerotized plate $[7,19]$. Frohawk [20] was the first to observe that most myrmecophilous butterfly 


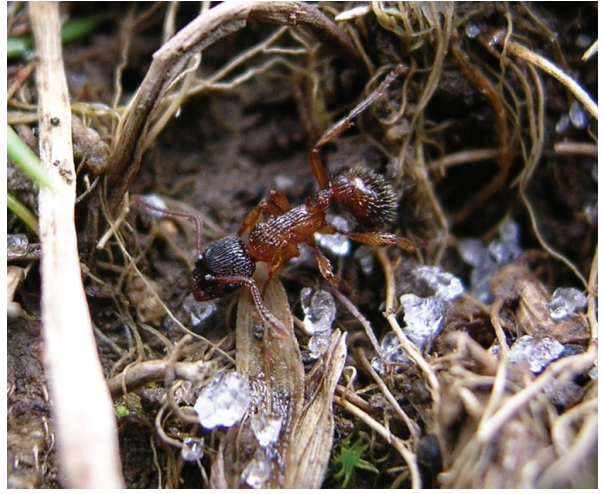

(a)

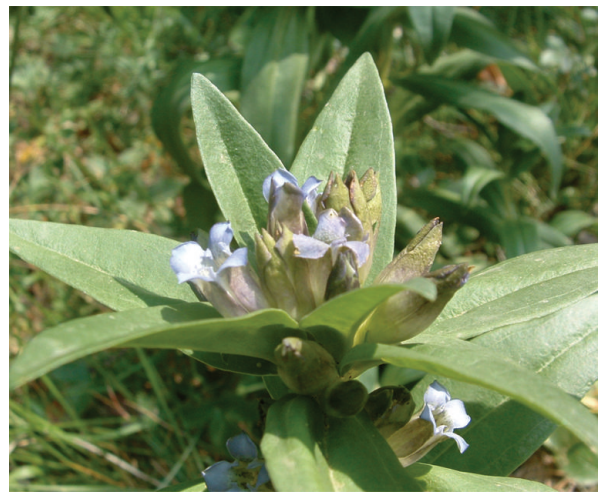

(c)

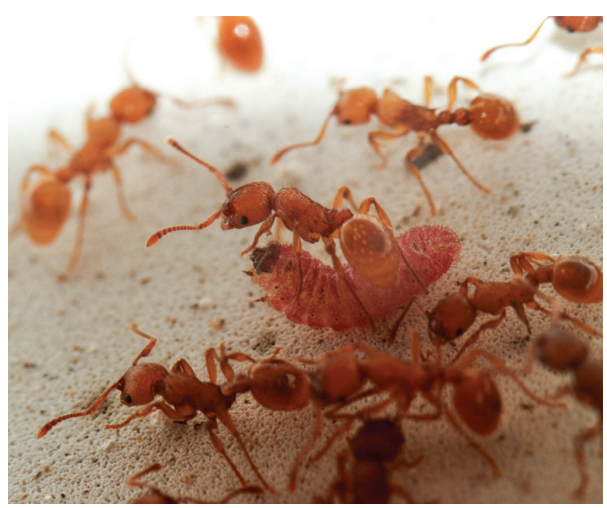

(b)

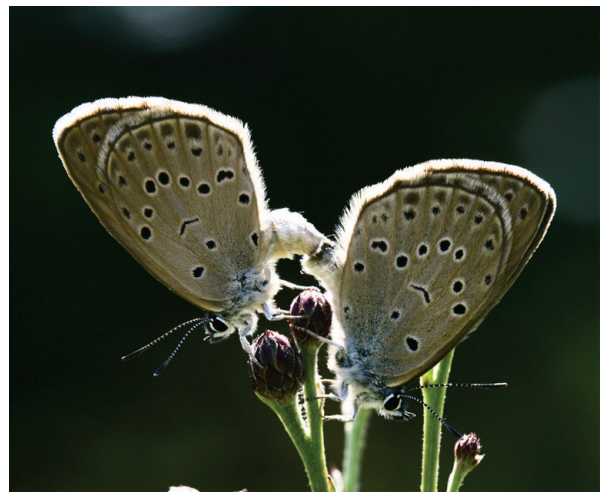

(d)

Figure 1: (a) Forager worker of Myrmica ant. (b) Trophallaxis between attendance worker and Maculinea larva. (c) Maculinea rebeli foodplant: Gentiana cruciata. (d) Mating of Maculinea butterflies.

larvae have dorsal nectar organs (DNOs), whose "honeydew" secretion attracts and pacifies ants, and plays an essential role in the maintenance of ant attendance [12]. Additionally, many lycaenoid caterpillars possess specialized epidermal glands, pore-cupola organs and tentacle organs, whose secretions are apparently not directly used by ants, but can somehow manipulate their behaviour [21-23]. Moreover, some butterfly species produce cohorts of other chemical and/or acoustical signals, which are involved in their interactions with ants [12].

\section{The Parasites: Maculinea Butterflies}

One of the most intensively studied systems in which both the communication channels are investigated concerns parasitic Maculinea butterfly larvae and their Myrmica host ants (Figures 1(a) and 1(b)) [24-26]. During the past decades butterflies of genus Maculinea (Figure 1(d)) have become "flagships" of European biodiversity conservation [24] and are perceived as umbrella species covering many grassland communities [27-29].

Some recent publications [30-32], based on both molecular and morphological data, have shown that species of Maculinea and Phengaris form a monophyletic group, where the three Chinese Phengaris species are basal. According to
Fric et al. [32] Maculinea Van Eecke, 1915 should be considered a junior subjective synonym of Phengaris Doherty, 1891. Possible alternatives are that Maculinea is, as subjectively, considered subgenus of Phengaris, or a distinct genus in its own right.

On the other end the obligate myrmecophilous life style of Maculinea has attracted a vast number of studies, many of which appeared in leading scientific journals. Maculinea is a model organism for studies on the origin and evolution of parasitic interactions and of host-parasite communication channels [11, 24-26, 30, 33].

Maculinea have also attracted a great deal of attention from a conservationist's point of view [34-37]. For this reason some of the authors have asked the International Commission on Zoological Nomenclature to conserve the name Maculinea against Phengaris in all cases when the two are considered subjective synonyms. The decision by the ICZN is still pending and we will continue to use Maculinea rather than Phengaris, at least for the moment.

Another point is that no molecular evidence is available to distinguish Maculinea rebeli from Maculinea alcon and some authors have argued that the first of them is an ecotype of M. alcon [32]. Also in this case we have decided to stick to the traditional interpretation that M. alcon and M. rebeli represent separate clades (species) and in this paper we 
will use the name Maculinea rebeli to designate what might represent the xerophilous ecotype of $M$. alcon.

European Maculinea species need urgent conservation actions, indeed four are mentioned in the European Red List of Butterflies and three of them are included in the Annex IV of the Habitats Directive $[38,39]$. These lycaenids are known for their very complex biological cycles. Maculinea species are all obligated parasites that depend on a particular food plant and on a specific Myrmica species for their survival. After having spent 10-15 days feeding on a species-specific host plant (Figure 1(c)), the 4th instar larvae of all Maculinea species drop to the ground and wait until they are found and carried into an ant nest by a Myrmica worker [40-44]. Once in the ant colony, Maculinea species differ in their alimentary strategy: (i) Maculinea alcon and Maculinea rebeli utilize a "cuckoo" strategy, and are mostly fed directly by attending workers (trophallaxis) [42] (Figures 1(a) and 1(b)), they are known for experiencing "contest" competition at high densities [45], (ii) Maculinea arion and Maculinea teleius are "predatory species" and directly prey on ant brood, experiencing "scramble" competition when overcrowded in the host colony [46], while (iii) the alimentary strategy of Maculinea nausithous has not yet been fully clarified, with some authors suggesting the coexistence of both "cuckoo" and "predatory" strategy and others considering it as a "cuckoo" species [24, 47]. Maculinea larvae spend 11 or 23 months inside their host colonies. In many populations two separate cohorts of larvae spending either one or two years inside the ants' nest are known to exist [33, 48-50]. The polymorphic growth pattern found in Maculinea populations is likely to have evolved for ergonomic, or perhaps hedge-betting reasons.

Two are the key moments in the life cycle of these butterflies: (i) the choice of an optimal food-plant on which to lay eggs and (ii) the first direct interaction with the host ants. The place where females lay their eggs is crucial for a myrmecophilous butterfly, to ensure its brood the chance to be adopted by a specific host ant. Because the worker ants' foraging range is limited, selecting an "ideal" oviposition site requires that both the phenological stage of the larval food plant (short-term larval fitness) and the presence of suitable host ants (long-term larval fitness) are taken into account. The female's selection of a valuable oviposition plant is influenced by a variety of factors. Plants are generally selected by females on the basis of their buds' phenology, while the presence of the host ants in the near surroundings of the plant may be variously insured depending on local situations and perhaps on the species. In some cases the host-plant and the Myrmica ant share a similar ecological niche, so that their overlap ensures population persistence [51-54]. In other cases, however, female butterflies mostly choose those plants which occur in the ants' foraging range [55-59]. To the best of the authors' knowledge, nothing is known about the mechanism providing butterfly females with the ability to discriminate among host plants placed inside/outside the foraging range of a Myrmica colony.

The other hot point of research on Maculinea butterflies is their host specificity with ants, both for its relevance in coevolutionary dynamics and as a background for conservation strategies. While Maculinea caterpillars induce workers of any Myrmica species to retrieve them by chemical and acoustical deception $[26,60]$, their survival till the adult stage will depend largely on which ant-species has found the larva $[41-44,61]$.

Before the 1970s a nonextensive study of Maculinea host specificity led scientists to consider all Myrmica species and, in some cases other ant's genera (e.g., Lasius), as potential host of these butterflies. In the following decades Thomas et al. [61] revealed a clear host specificity pattern involving each of the five European Maculinea species. In their work authors demonstrated that the survival of every Maculinea species was linked to single and different Myrmica ant species, while the adoption by a non-host species caused a large decrease in the survival rate of these butterflies. More recently, the large amount of data collected by many researchers all across Europe, confirmed these general guidelines, but demonstrated that host specificity patterns are much more complex and hosts may vary geographically all along the range of each Maculinea butterfly. The only species that apparently keeps a single host is M. nausithous [34, 62, 63], which shows a clear adaptation to Myrmica rubra all over its distribution $[47,61,62,64]$. The only known exception to this occurs in Transylvania, where it exploits M. scabrinodis as alternative host [65]. Data on other Maculinea species show a much more complicated pattern, which demonstrates that host specificity occurs at the population or, at least, at the regional scale. Several works have shown that M. teleius, M. arion, M. alcon, and M. rebeli may be locally adapted to some Myrmica species previously considered as nonhost $[29,50,64-72]$ and in the case of the latter two species have developed the ability to successfully exploit more than one host species in the same site creating real multiple host populations $[25,73]$.

\section{The Host: Myrmica Ants}

Myrmica ants are hosts of Maculinea butterflies, but their colonies are infested by numerous other social parasites such as the larvae of the hoverfly Microdon myrmicae (Diptera Syrphidae; see $[74,75]$ ), or by parasitic ant species of the same genus [76]. Reasons for this apparent asymmetry are unclear, but may be related to the biological cycle of these ants. The genus Myrmica has a Holarctic distribution. Most of the species, however, are found in Europe and Asia, while a smaller proportion occurs in North America [77]. Colonies are widespread and can be found in various kinds of habitat, such as meadows, forests, steppes, or mountains [76]. Although the biology of many Myrmica species has not been studied in detail, it seems that a general life style is common to all ants of this genus [76]. Most colonies contain on average $200-500$ workers, as well as from one to many functional queens $[78,79]$. New nests can be either funded by a single newly mated queen or, more often, by budding preexisting colonies [45]. Oviposition starts in early spring and lasts throughout the summer, while it stops in autumn when temperature is decreasing [76]. Part of the larvae develop rapidly but others enter diapause and overwinter. The latter 

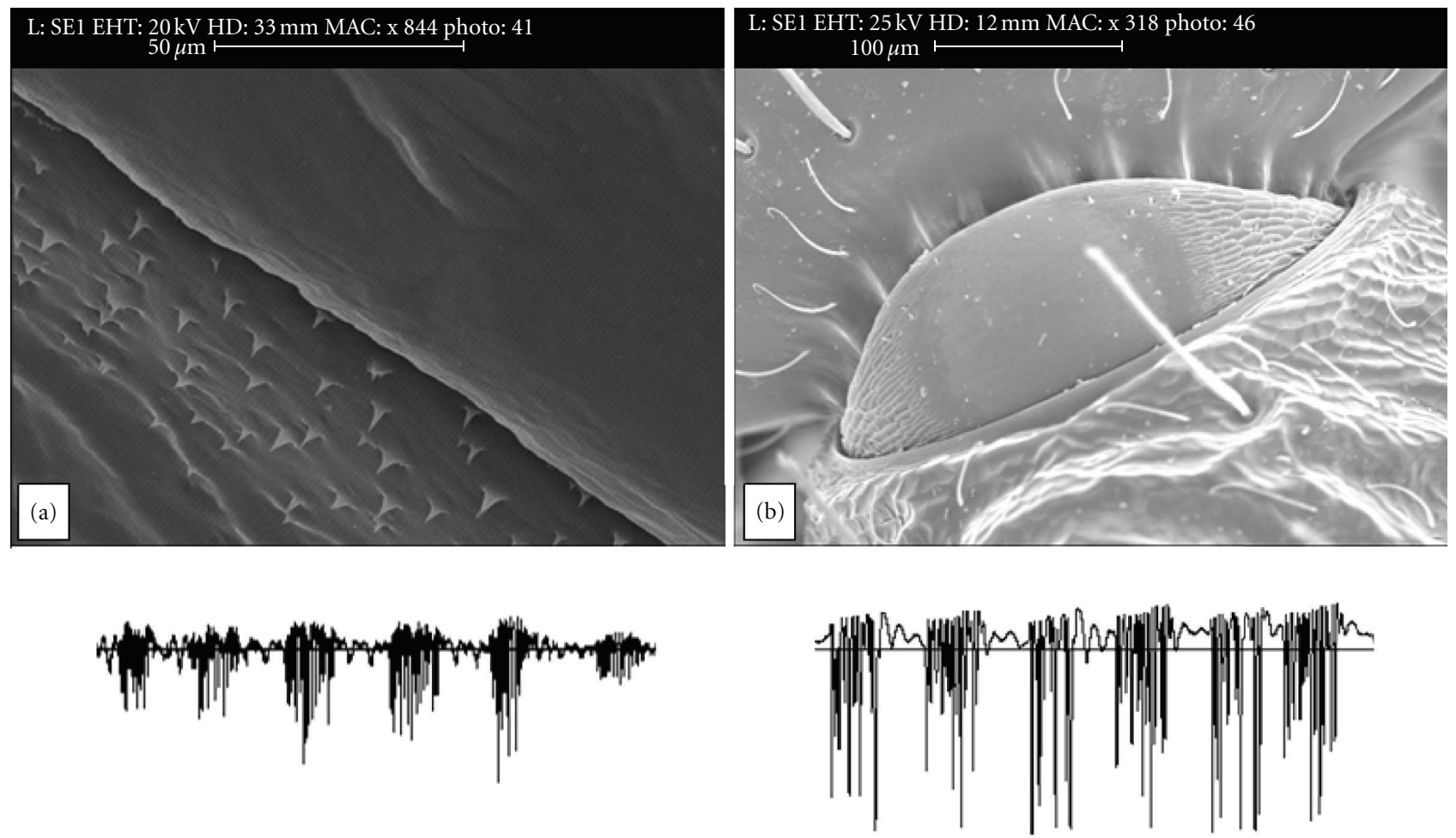

FIgure 2: Morphology (upper part) and sounds (lower part) of the acoustical organs of (a) Maculinea rebeli pupa and (b) Myrmica schencki queen.

group includes both workers and all the gyne-potential larvae [80]. Some of these life history traits of Myrmica ants make them more vulnerable to infestations by social parasites. One of the most important is presence of overwintered ant larvae particularly essential for survival of the predatory Maculinea larvae, which start their intensive growth inside host colony at the beginning of spring and use overwintered ant brood as their food resource $[49,81]$. Another significant trait that make Myrmica ants a proper host for many social parasites is that many Myrmica species live in polygynous colonies and some of them such as $M$. rubra, M. ruginodis, or $M$. rugulosa may contain a relatively high number of workers $[76,77]$. This results in lower relatedness among worker nest mates [78, 82]. Many studies [83-85] showed that high genetic variance may be beneficial for social insects colonies, but it can also increase the likelihood of being infested by social parasites, because of the greater variance in nest mate recognition cues. It was indicated that Microdon mutabilis (Linnaeus, 1758) (Diptera: Syrphidae), a social parasite of Formica lemani ants, more often infests host colonies where genetic relatedness is lower [86]. A similar situation was found for colonies of M. rubra infested by M. alcon [87]. Therefore, a cost of polygyny existing in most of Myrmica species is that their colony communication signals (e.g., chemical or acoustical) tend to be broader and more heterogeneous than in monogynous ant species and their colonies can be more easily invaded by cheats that mimic these signals.

\section{Acoustical Pattern in the Maculinea-Myrmica System}

The more fine-tuned the host-parasite relationship is, the more intriguing studying how the host's deception can be achieved is. The communication of social insects is mainly based on chemical cues [1], but also the acoustic channel is used, thus it is clear that the parasite has to bypass the host's chemical and acoustical system to enter and live in its colonies [88].

Cuticular hydrocarbons have long been assumed to play a fundamental role in the nest mate recognition of social insects. All individuals living in the same society share a bouquet of chemicals, which serves as a "colony odour" and enables them to discriminate between nest mates and strangers. Additional variation in hydrocarbon pattern is associated with differences in sex, caste, and developmental stage $[89,90]$. The fact that caterpillars of Maculinea butterflies use chemical mimicry to become adopted and to infiltrate colonies of their hosts was first proposed by Elmes et al. [42], while the first experimental evidence was produced by Akino et al. [43], who found that the chemical profile of Maculinea rebeli resembles that of its host more than those of other Myrmica species.

Even though sound production is not usually the dominant strategy, acoustic communication plays a fundamental role in some groups of insects [91]. Depending on the taxon, sound productions may have a number of functions, ranging 
from mate attraction to courtship, aggression, defence, or recruitment of foragers, at least in social insects. Recently, it has been suggested that sounds play a role in the modulation of other signals. This was demonstrated to occur at least in honey bees [92-96].

The role of stridulations in ant communication was underestimated for a long time $[8,26]$, also because of our scant understanding of the structures involved in the production and the reception of the acoustic signals. Stridulations, however, have long been known to occur in 4 ant subfamilies $[97,98]$. In these ants, sounds are produced by a minutely ridged stridulating organ (pars stridens) positioned on the middle-dorsal part of the 4th "abdominal" segment and by a spike (plectrum) jutting from the postpetiole's rear margin [26, 99-103] (Figure 2(b)). When an ant moves its abdomen, the two parts rub on each other and emit a series of "chirps" $[1,103,104]$. Stridulations are variously defined depending on the transmitting medium. They are sounds, when transmitted by air, or vibrations, if transmitted by substrate. Myrmecologists have long believed that ants cannot "hear" the aerial component of a stridulation but perceive substratetransmitted vibrations [105]. This notion was based on experience obtained in the early 20th century $[106,107]$, and has been indirectly confirmed ninety years later by the discovery of a subgenual organ in Camponotus ants [108]. More recently, however, a seminal paper by Hickling and Brown [105] provided fresh impulse to studies on the possible perception of air-transmitted sounds heating the debate on this subject $[109,110]$. Hickling and Brown [105] maintain that ants cannot perceive the aerial component of sounds over a long distance (i.e., $1 \mathrm{~m}$ ), but largely use short range acoustic communication (i.e., $1 \mathrm{~cm}$ ).

Acoustic communication plays a wide range of roles in the ants' social behaviour, from reciprocal attraction to intercaste interactions. In most cases, these stimuli are effective only at small range and are mainly used as signals of alarm, for foragers' recruitment, mating requests, intimidation, and aposematic "threatening", as well as to modulate other kinds of signals $[1,92,111-118]$.

Functions of stridulations have been intensively surveyed in Atta ants, where foragers' calls are most frequent when leaves of the highest quality for fungal cultures are found [119]. Myrmica workers frequently stridulate during trophallaxis, particularly the receiving worker, when food decreases $[120,121]$. Intercaste acoustical communication has been recorded in only a few instances. Mating queens of Pogonomyrmex badius stridulate to signal to males when their spermathecae are full [111] whereas, in Atta, leafcutting workers stridulate when they are ready to return to the nest. This behaviour induces individuals of the smallest "minim" caste to climb onto the leaf fragment where from there they protect their larger sisters from attack by phorid flies during the journey home [117]. Until recently, there was no direct evidence that different members of an ant society produced distinctive caste-specific sounds to induce appropriate patterns of behaviour either in fellows or in other castes. At least two studies, however, suggested that different castes produce distinctive signals: the major workers of Atta cephalotes make sounds that are more intense and carry further than those of their smaller nest mates [122], while the space between the ridges of the pars stridens of queens exceeds that of workers in four Messor species [102].

Our own findings demonstrated that Myrmica schencki queens generate distinctive sounds that elicit increased benevolent responses from workers, thereby reinforcing their supreme social status $[26,123]$. These findings demonstrated that acoustical communication within the vast subfamily Myrmicinae (to which Messor spp. and Myrmica spp. belong) is more variable and conveys more social information within ant colonies than was previously recognized. In this group, stridulations also fulfil the strict adaptationist definition of biological communication, in which both the signal and the response are adaptive [26, 124, 125].

Since acoustic signals convey quite complex information, not only between worker ants while outside the colony (e.g., during foraging), but also within the nest and between castes, we started research aimed at understanding whether some social parasites, such as butterfly larvae, could interfere with this communication system. Lycaenid larvae, in fact, have long been known to be able to emit stridulations even if their life cycle is not linked at any degree to the ant presence, but sounds produced by myrmecophilous species are more complex and frequent than those emitted by nonmyrmecophilous species [22]. More in general, however, studies aiming at clarifying the function of interspecific acoustic communication in myrmecophilous Lepidoptera are scarce. Most of these studies considered butterfly larva stridulations as a merely defensive signals $[6,126]$ or, more rarely, as aggregation messages [127]. Sounds produced by lycaenid pupae and caterpillars originate from different organs; the former from tooth-and-comb stridulatory organs between the fifth and sixth segments [12, 126, 128, 129] (Figure 2(a)), whereas caterpillar sounds may emanate from muscular contraction and air compression through the tracheae [130]. The acoustics of mutualistic lycaenid species does not obviously mimic ant stridulations, and ants attraction has been demonstrated only in the pupae of one extreme mutualist species (i.e., Jalmenus evagoras see $[12,131]$. On the contrary, the larval calls of four Maculinea species are similar in pulse rate and band width to those of their hosts, although the level of apparent mimicry is to the genus Myrmica rather than to individual host ant species [132]. The same study showed that Myrmica larvae are mute, suggesting that in this trait Maculinea caterpillars are mimicking an adult ant cue, but no direct cause-andeffect relationship was revealed (recordings by DeVries et al. [132] were restricted to distressed worker ants and caterpillars, and were not played back to the ants). Studying the Maculinea rebeli/Myrmica schencki system, we recently demonstrated the first case of acoustical mimicry in an ant social parasite [26]. In particular we demonstrated that Maculinea rebeli larvae and pupae are able to mimic the sounds produced by Myrmica schencki queens (Figures 2(a) and 2(b)), thus obtaining a high status in the host colony hierarchy. Queens, that never come out of the nest, produce peculiar stridulations, which attract workers. Ethological experiments revealed that the acoustical signals produced by Maculinea rebeli larvae elicit the same benevolent responses 
in the worker ants as those emitted by their queen(s). When recordings of unstressed adult $M$. schencki were played back to laboratory cultures of workers, the sounds of both castes induced benign responses including aggregation and antennation at the speaker. Moreover, when workers were played their queen's sounds, they stood "on guard" on the speaker to a much greater extent than when worker sounds were played, each holding the characteristic posture adopted by a Myrmica worker when protecting an object of high value to the colony [26]. Maculinea rebeli caterpillars are rescued ahead of the ant brood when a colony is disturbed, and are fed in preference to host ant larvae when food is scarce [48]. Neither chemical mimicry nor their begging behaviour explains why $M$. rebeli caterpillars are treated in preference to host ant brood. Instead, we have suggested that acoustical cues are employed [26].

Thus it is possible that acoustical mimicry does not occur in Maculinea rebeli only, but rather provides another route for the infiltration of other Maculinea species, as well as for other myrmecophilous insects [26]. Acoustical mimicry can also be related to the level of interaction between host and parasite, or may play a role in host-specificity. In particular, in the Maculinea/Myrmica system the level of host's integration within the colony results from the two distinct parasites' foraging strategies. In the so-called "cuckoo" species, Maculinea larvae become perfectly integrated members of the colony, as they need to be tended by worker ants. Larvae of predator species, in contrast, will prey on the ants' brood and spend much of their life hidden in the remote chambers of the nest. DeVries et al. [132] showed that also the caterpillars of the predatory Maculinea species produce sounds that appear to mimic Myrmica (worker) stridulations, although in nature they are less closely integrated with their host's society [14], so that they might be less perfect acoustical mimics of their hosts. We tested [124] this hypothesis by comparing the acoustics of unstressed Maculinea arion caterpillars and pupae with those of the queens and workers of its host ant, Myrmica sabuleti, and with data obtained for Maculinea rebeli and Myrmica schencki, but found no evidence that $M$. rebeli is a closer mimic of $M$. schencki than M. arion is to M. sabuleti [26]. We also compared the worker and queen sounds of $M$. sabuleti, and those of two other ants, Myrmica scabrinodis and M. schencki, to determine whether the distinctive acoustical communication system occurring in the different castes of $M$. schencki exists in its congeners.

We found that stridulating queens from two additional Myrmica species (i.e., M. sabuleti and M. scabrinodis) make distinctive sounds from those of their workers by using morphologically distinct organs [124]. Interestingly, the calls produced by queen from the three Myrmica species were indistinguishable from each other, as were workers' stridulations even at a less extent. This suggests that acoustics plays little or no part in the cues used by Myrmica to distinguish between kin and nonkin, or other species of ant and members of their own society. Indeed numerous studies demonstrate the predominant role of chemical cues and the gestalt odour in colony recognition or between physiological states within an ant society [1]. However, our recent results suggest that acoustical communication, in isolation, is capable of signalling at least the caste and the status of a colony member, as well as of inducing appropriate behaviour towards it by the attending workers [124]. In other words, acoustical mimicry is genus rather than species specific, as DeVries et al. [132] concluded. We have not yet studied whether different castes of Myrmica ants responded differently when played the same sounds, although this seems probable, because Myrmica schencki queen respond aggressively when introduced to Maculinea rebeli pupae (which mimic queen sounds) whereas the workers tend them gently [26].

\section{Concluding Remarks}

To our knowledge, although 10,000 species of ant social parasites may exist [24] particularly among the Coleoptera, Diptera and Lepidoptera [1], acoustical mimicry has rarely been examined outside the case of Maculinea. Together with Di Giulio and his collaborators, we recently surveyed the acoustical emissions of Paussus favieri (Coleoptera, Paussinae), a myrmecophilous paussine beetle which lives in the nests of the ant Pheidole pallidula [133]. The presence of stridulatory organs in members of the myrmecophilous ground beetles tribe Paussini has long been known. However, due to the rarity of these beetles and the challenges in rearing them in captivity, sounds emitted by these organs have never been investigated, as well as their biological significance. The complexity of $P$. favieri's sound repertoire suggests that it has an important role in its interaction with $P$. pallidula.

We strongly believe that the implementation of studies on acoustic communication will bring about significant advances in our understanding of the complex mechanisms underlying the origin, evolution and stabilisation of hostparasite relationships. To improve our understanding of how important and how generalised acoustic mimicry is we also need to clarify which sensory structures are involved in sound perception processes, both in queen and worker ants. Nobody, so far, has ever investigated the possibility that the larvae and pupae of myrmecophilous lycaenids may perceive the sounds emitted by conspecifics, or by their host ants. In this respect it is worth noticing that some of the most important research on the role of filiform hairs in sound perception (e.g., $[134,135])$ were carried out on Barathra brassicae (Lepidoptera: Noctuidae). The larvae of this moth, indeed, are able to detect the vibrations produced by a parasitoid wasp, by their thoracic hairs.

\section{Acknowledgments}

The authors would like to thank all the colleagues of the MacMan project. The research has been carried out within the project CLIMIT (Climate Change Impacts on Insects and Their Mitigation [37]) funded by DLR-BMBF (Germany), NERC and DEFRA (UK), ANR (France), Formas (Sweden), and Swedish EPA (Sweden) through the FP6 BiodivERsA Eranet as well as within the project A Multitaxa Approach to Study the Impact of Climate Change on the Biodiversity of Italian Ecosystems funded by the Italian Ministry of University and Research (MIUR). 


\section{References}

[1] B. Hölldobler and E.O. Wilson, The Ants, Springer, Berlin, Germany, 1990.

[2] J. A. Thomas, "Relationships between butterflies and ants," in The Ecology of British Butterflies, R. L. H. Dennis, Ed., pp. 149-154, Oxford University Press, Oxford, UK, 1992.

[3] J. A. Thomas, "Adaptations to living near ants," in The Ecology of British Butterflies, R. L. H. Dennis, Ed., pp. 109-115, Oxford University Press, Oxford, UK, 1992.

[4] E. Wasmann, Kritisches Verzeichniss der Myrmecophilen und Termitophilen Arthropoden, Felix Dames, Berlin, Germany, 1894.

[5] H. S. J. K. Donisthorpe, The Guests of British Ants, Routledge, London, UK, 1927.

[6] H. E. Hinton, "Myrmecophilous Lycaenidae and other Lepidoptera- a summary," Proceedings and Transactions of South London Entomological Natural History Society, vol. 19491950, pp. 111-175, 1951.

[7] H. Malicky, "New aspects of association between lycaenid larvae (Lycaenidae) and ants (Formicidae, Hymenoptera)," Journal of the Lepidopterists Society, vol. 24, pp. 190-202, 1970.

[8] P. J. DeVries, "Call production by myrmecophilous riodinid and lycaenid butterfly caterpillars (Lepidoptera): morphological, acoustical, functional, and evolutionary patterns," American Museum Novitates, vol. 3025, pp. 1-23, 1991.

[9] P. J. DeVries, "Evolutionary and ecological patterns in myrmecophilous riodinid and butterflies," in Ant-Plant Interactions, C. R. Huxley and D. F. Cutler, Eds., pp. 143-156, Oxford University Press, Oxford, UK, 1991.

[10] K. Fiedler, "Systematic, evolutionary and ecological implications of myrmecophily within the Lycaenidae (Insecta: Lepidoptera: Papilionoidae)," Bonner Zoologische Monographien, vol. 31, pp. 1-210, 1991.

[11] K. Fiedler, "Lycaenid-ant interactions of the Maculinea type: tracing their historical roots in a comparative framework," Journal of Insect Conservation, vol. 2, no. 1, pp. 3-14, 1998.

[12] N. E. Pierce, M. F. Braby, A. Heath et al., "The ecology and evolution of ant association in the Lycaenidae (Lepidoptera)," Annual Review of Entomology, vol. 47, pp. 733-771, 2002.

[13] K. Fiedler and B. Hölldobler, "Ants and Polyommatus icarus immatures (Lycaenidae) -sex-related developmental benefits and costs of ant attendance," Oecologia, vol. 91, no. 4, pp. 468-473, 1992.

[14] J. A. Thomas, K. Schönrogge, and G. W. Elmes, "Specializations and host associations of social parasites of ants," in Insect Evolutionary Ecology, M. D. E. Fellowes, G. J. Holloway, and J. Rolff, Eds., pp. 475-514, CABI Publishing, Reading, UK, 2005.

[15] W. M. Wheeler, Ants: Their Structure, Development and Behaviour, Columbia University Press, New York, NY, USA, 1910.

[16] J. A. Thomas, "Why did the large blue become extinct in Britain?” Oryx, vol. 15, pp. 243-247, 1980.

[17] J. A. Thomas and M. G. Morris, "Patterns, mechanisms and rates of extinction among invertebrates in the United Kingdom," Philosophical Transactions, vol. 344, no. 1307, pp. 47-54, 1994.

[18] P. R. Aekery, R. De Jong, and R. I. Vane-Wright, "The butterflies: hedyloidea, hesperoidea, and papilionoidea," Handbook of Zoology, vol. 4, pp. 263-300, 1999.

[19] E. B. Sliwinska, P. Nowicki, D. R. Nash, M. Witek, J. Settele, and M. Woyciechowski, "Morphology of caterpillars and pupae of European Maculinea species (Lepidoptera: Lycaenidae) with an identification table," Entomologica Fennica, vol. 17, no. 4, pp. 351-358, 2006.

[20] F. W. Frohawk, Natural History of British Butterflies: A Complete, Original, Descriptive Account of the Life-History of Every Species Occurring in the British Islands, Together with Their Habits, Times of Appearance, and Localities, Hutchinson, London, UK, 1924.

[21] A. H. Axén, O. Leimar, and V. Hoffman, "Signalling in a mutualistic interaction," Animal Behaviour, vol. 52, no. 2, pp. 321-333, 1996.

[22] K. Fiedler, B. Hölldobler, and P. Seufert, "Butterflies and ants: the communicative domain," Experientia, vol. 52, no. 1, pp. 14-24, 1996.

[23] P. J. DeVries and G. O. Poinar, "Ancient butterfly-ant symbiosis: direct evidence from Dominican amber," Proceedings of the Royal Society B, vol. 264, no. 1385, pp. 1137-1140, 1997.

[24] J. A. Thomas and J. Settele, "Butterfly mimics of ants," Nature, vol. 432, no. 7015, pp. 283-284, 2004.

[25] D. R. Nash, T. D. Als, R. Maile, G. R. Jones, and J. J. Boomsma, "A mosaic of chemical coevolution in a large blue butterfly," Science, vol. 319, no. 5859, pp. 88-90, 2008.

[26] F. Barbero, J. A. Thomas, S. Bonelli, E. Balletto, and K. Schönrogge, "Queen ants make distinctive sounds that are mimicked by a butterfly social parasite," Science, vol. 323, no. 5915, pp. 782-785, 2009.

[27] Z. Randle, D. J. Simcox, K. Schönrogge, J. C. Wardlaw, and J. A. Thomas, "Myrmica ants as keystone species and Maculinea arion as an indicator of rare niches in UK grasslands," in Studies on the Ecology and Conservation of Butterflies in Europe. Species Ecology Along a European gradient: Maculinea Butterflies as a Model, J. Settele, E. Kühn, and J. A. Thomas, Eds., vol. 2, pp. 26-27, Pensoft, Sofia, Moscow, 2005.

[28] L. Spitzer, J. Benes, J. Dandova, V. Jaskova, and M. Konvicka, "The Large Blue butterfly, Phengaris [Maculinea] arion, as a conservation umbrella on a landscape scale: the case of the Czech Carpathians," Ecological Indicators, vol. 9, no. 6, pp. 1056-1063, 2009.

[29] L. P. Casacci, M. Witek, F. Barbero et al., "Habitat preferences of Maculinea arion and its Myrmica host ants: implications for habitat management in Italian Alps," Journal of Insect Conservation, vol. 15, no. 1-2, pp. 103-110, 2011.

[30] T. D. Als, R. Vila, N. P. Kandul et al., "The evolution of alternative parasitic life histories in large blue butterflies," Nature, vol. 432, no. 7015, pp. 386-390, 2004.

[31] P. Pech, Z. Fric, M. Konvička, and J. Zrzavý, "Phylogeny of Maculinea blues (Lepidoptera: Lycaenidae) based on morphological and ecological characters: evolution of parasitic myrmecophily," Cladistics, vol. 20, no. 4, pp. 362-375, 2004.

[32] Z. Fric, N. Wahlberg, P. Pech, and J. Zrzavý, "Phylogeny and classification of the Phengaris-Maculinea clade (Lepidoptera: Lycaenidae): total evidence and phylogenetic species concepts," Systematic Entomology, vol. 32, no. 3, pp. 558-567, 2007.

[33] T. Hovestadt, O. Mitesser, G. W. Elmes, J. A. Thomas, and M. E. Hochberg, "An evolutionarily stable strategy model for the evolution of dimorphic development in the butterfly Maculinea rebeli, a social parasite of Myrmica ant colonies," American Naturalist, vol. 169, no. 4, pp. 466-480, 2007.

[34] M. J. Munguira and J. Martin, Action Plan for Maculinea Butterflies in Europe, Nature and Environment no. 97, Council of Europe Publishing, Bern, Switzerland, 1999. 
[35] C. Van Swaay and M. Warren, Prime Butterfly Areas in Europe: Priority Sites for Conservation, De Vlinderstickting Wageningen, Wageningen, The Netherlands, 2003.

[36] J. A. Thomas, D. J. Simcox, and R. T. Clarke, "Successful conservation of a threatened Maculinea butterfly," Science, vol. 325, no. 5936, pp. 80-83, 2009.

[37] J. Settele and E. Kühn, "Insect conservation," Science, vol. 325, no. 5936, pp. 41-42, 2009.

[38] C. Van Swaay, A. Cuttelod, S. Collins et al., European Red List of Butterflies, Publications Office of the European Union Luxembourg, 2010.

[39] P. J. Van Helsdingen, L. Willemse, and M. C. D. Speight, Background Information on Invertebrates of the Habitats Directive and the Bern Convention. Part I- Crustacea, Coleoptera and Lepidoptera, Nature and Environment no. 79, Council of Europe Publishing, Strasbourg, France, 1996.

[40] J. A. Thomas, "The behaviour and habitat requirements of Maculinea nausithous (the dusky large blue butterfly) and $M$. teleius (the scarce large blue) in France," Biological Conservation, vol. 28, no. 4, pp. 325-347, 1984.

[41] J. A. Thomas, "Larval niche selection and evening exposure enhance adoption of a predacious social parasite, Maculinea arion (large blue butterfly), by Myrmica ants," Oecologia, vol. 132, no. 4, pp. 531-537, 2002.

[42] G. W. Elmes, J. A. Thomas, and J. C. Wardlaw, "Larvae of Maculinea rebeli, a large-blue butterfly, and their Myrmica host ants: wild adoption and behaviour in ant-nests," Journal of Zoology, vol. 223, no. 3, pp. 447-460, 1991.

[43] T. Akino, J. J. Knapp, J. A. Thomas, and G. W. Elmes, "Chemical mimicry and host specificity in the butterfly Maculinea rebeli, a social parasite of Myrmica ant colonies," Proceedings of the Royal Society B, vol. 266, no. 1427, pp. 1419-1426, 1999.

[44] G. W. Elmes, T. Akino, J. A. Thomas, R. T. Clarke, and J. J. Knapp, "Interspecific differences in cuticular hydrocarbon profiles of Myrmica ants are sufficiently consistent to explain host specificity by Maculinea (large blue) butterflies," Oecologia, vol. 130, no. 4, pp. 525-535, 2002.

[45] J. A. Thomas, G. W. Elmes, and J. C. Wardlaw, "Contest competition among Maculinea rebeli butterfly larvae in ant nests," Ecological Entomology, vol. 18, no. 1, pp. 73-76, 1993.

[46] J. A. Thomas and J. C. Wardlaw, "The capacity of a Myrmica ant nest to support a predacious species of Maculinea butterfly," Oecologia, vol. 91, no. 1, pp. 101-109, 1992.

[47] D. Patricelli, M. Witek, F. Barbero, L. P. Casacci, S. Bonelli, and E. Balletto, "Evidence of high larvai host ant (hymenoptera: Formicidae) specificity in the first post-adoption phase for the myrmecophilous butterfly phengaris (Maculinea) nausithous (lepidoptera: Lycaenidae)," Sociobiology, vol. 55, no. 3, pp. 861-870, 2010.

[48] J. A. Thomas, G. W. Elmes, and J. C. Wardlaw, "Polymorphic growth in larvae of the butterfly Maculinea rebeli, a social parasite of Myrmica ant colonies," Proceedings of the Royal Society B, vol. 265, no. 1408, pp. 1895-1901, 1998.

[49] K. Schönrogge, J. C. Wardlaw, J. A. Thomas, and G. W. Elmes, "Polymorphic growth rates in myrmecophilous insects," Proceedings of the Royal Society B, vol. 267, no. 1445, pp. 771777, 2000.

[50] M. Witek, E. B. Sliwinska, P. Skórka, P. Nowicki, J. Settele, and M. Woyciechowski, "Polymorphic growth in larvae of Maculinea butterflies, as an example of biennialism in myrmecophilous insects," Oecologia, vol. 148, no. 4, pp. 729-733, 2006.
[51] J. A. Thomas and G. W. Elmes, "Food-plant niche selection rather than the presence of ant nests explains oviposition patterns in the myrmecophilous butterfly genus Maculinea," Proceedings of the Royal Society B, vol. 268, no. 1466, pp. 471477, 2001.

[52] P. Nowicki, M. Witek, P. Skórka, and M. Woyciechowski, "Oviposition patterns in the myrmecophilous butterfly Maculinea alcon Denis \& Schiffermüller (Lepidoptera: Lycaenidae) in relation to characteristics of foodplants and presence of ant hosts," Polish Journal of Ecology, vol. 53, no. 3, pp. 409417, 2005.

[53] M. Musche, C. Anton, A. Worgan, and J. Settele, "No experimental evidence for host ant related oviposition in a parasitic butterfly," Journal of Insect Behavior, vol. 19, no. 5, pp. 631643, 2006.

[54] M. A. Fürst and D. R. Nash, "Host ant independent oviposition in the parasitic butterfly Maculinea alcon," Biology Letters, vol. 6, no. 2, pp. 174-176, 2010.

[55] D. Patricelli, F. Barbero, V. La Morgia et al., "To lay or not to lay: oviposition of Maculinea arion in relation to Myrmica ant presence and host plant phenology," Animal Behaviour, vol. 82, no. 4, pp. 791-799, 2011.

[56] M. Scheper, J. G. Van der Made, and I. Wynhoff, “Maculinea alcon: interactions between a myrmecophilous butterfly its larval foodplant and its host ant," in Proceedings of the Experimental and Applied Entomology NEVAmsterdam, vol. 6, pp. 77-78, 1995.

[57] H. Van Dyck, J. G. B. Oostermeijer, W. Talloen, V. Feenstra, A. Van Der Hidde, and I. Wynhoff, "Does the presence of ant nests matter for oviposition to a specialized myrmecophilous Maculinea butterfly?" Proceedings of the Royal Society B, vol. 267, no. 1446, pp. 861-866, 2000.

[58] I. Wynhoff, M. Grutters, and F. Van Langevelde, "Looking for the ants: selection of oviposition sites by two myrmecophilous butterfly species," Animal Biology, vol. 58, no. 4, pp. 371-388, 2008.

[59] H. Van Dyck and S. Regniers, "Egg spreading in the antparasitic butterfly, Maculinea alcon: from individual behaviour to egg distribution pattern," Animal Behaviour, vol. 80, no. 4, pp. 621-627, 2010.

[60] K. Schönrogge, J. C. Wardlaw, A. J. Peters, S. Everett, J. A. Thomas, and G. W. Elmes, "Changes in chemical signature and host specificity from larval retrieval to full social integration in the myrmecophilous butterfly Maculinea rebeli," Journal of Chemical Ecology, vol. 30, no. 1, pp. 91-107, 2004.

[61] J. A. Thomas, G. W. Elmes, J. C. Wardlaw, and M. Woyciechowski, "Host specificity among Maculinea butterflies in Myrmica ant nests," Oecologia, vol. 79, no. 4, pp. 452-457, 1989.

[62] G. W. Elmes, J. A. Thomas, J. C. Wardlaw, M. E. Hochberg, R. T. Clarke, and D. J. Simcox, "The ecology of Myrmica ants in relation to the conservation of Maculinea butterflies," Journal of Insect Conservation, vol. 2, no. 1, pp. 67-78, 1998.

[63] M. Witek, E. B. Śliwińska, P. Skórka et al., "Host ant specificity of large blue butterflies Phengaris (Maculinea) (Lepidoptera: Lycaenidae) inhabiting humid grasslands in Eastcentral Europe," European Journal of Entomology, vol. 105, no. 5, pp. 871-877, 2008.

[64] A. Tartally and Z. Varga, "Host-ant specificity of Maculinea species in Hungary, connection with parasitoids and host plants," in Studies on the Ecology and Conservation of Butterflies Along a European Gradient: Maculinea Butterflies as a Model, J. Settele, E. Kühn, and J. A. Thomas, Eds., vol. 2, Pensoft, Sofia, Moscow, 2005. 
[65] A. Tartally, D. R. Nash, S. Lengyel, and Z. Varga, "Patterns of host ant use by sympatric populations of Maculinea alcon and M. 'rebeli' in the Carpathian Basin," Insectes Sociaux, vol. 55, no. 4, pp. 370-381, 2008.

[66] G. W. Elmes, J. A. Thomas, O. Hammarstedt, M. Lopez Munguira, J. Martin, and J. G. Van Der Made, "Differences in host-ant specificity between Spanish, Dutch and Swedish populations of the endangered butterfly, Maculinea alcon (Denis et Schiff.) (Lepidoptera)," Memorabilia Zoologica, vol. 48, pp. 55-68, 1994.

[67] M. Sielezniew, D. Patricelli, I. Dziekańska et al., "The first record of Myrmica lonae (Hymenoptera: Formicidae) as a host of the socially parasitic Large Blue butterfly Phengaris (Maculinea) arion (Lepidoptera: Lycaenidae)," Sociobiology, vol. 56, no. 2, pp. 465-475, 2010.

[68] F. M. Steiner, M. Sielezniew, B. C. Schlick-Steiner, H. Höttinger, A. Stankiewicz, and A. Górnicki, "Host specificity revisited: new data on Myrmica host ants of the lycaenid butterfly Maculinea rebeli," Journal of Insect Conservation, vol. 7, no. 1, pp. 1-6, 2003.

[69] M. Sielezniew and A. M. Stankiewicz, "Simultaneous exploitation of Myrmica vandeli and M. scabrinodis (Hymenoptera: Formicidae) colonies by the endangered myrmecophilous butterfly Maculinea alcon (Lepidoptera: Lycaenidae)," European Journal of Entomology, vol. 101, no. 4, pp. 693-696, 2004.

[70] M. Sielezniew and A. M. Stankiewicz, "Differences in the development of the closely related myrmecophilous butterflies Maculinea alcon and M. rebeli (Lepidoptera: Lycaenidae)," European Journal of Entomology, vol. 104, no. 3, pp. 433-444, 2007.

[71] M. Sielezniew and A.M. Stankiewicz-Fiedurek, "Host ant use by Phengaris (=Maculinea) alcon in Poland," Polish Journal of Entomology, vol. 78, pp. 323-335, 2009.

[72] A. Tartally and Z. Varga, "Host ant use of Maculinea teleius in the Carpathian Basin (Lepidoptera: Lycaenidae)," Acta Zoologica Academiae Scientiarum Hungaricae, vol. 54, no. 3, pp. 257-268, 2008.

[73] T. D. Als, D. R. Nash, and J. J. Boomsma, "Geographical variation in host-ant specificity of the parasitic butterfly Maculinea alcon in Denmark," Ecological Entomology, vol. 27, no. 4, pp. 403-414, 2002.

[74] K. Schönrogge, B. Barr, J. C. Wardlaw et al., "When rare species become endangered: cryptic speciation in myrmecophilous hoverflies," Biological Journal of the Linnean Society, vol. 75, no. 3, pp. 291-300, 2002.

[75] S. Bonelli, M. Witek, S. Canterino et al., "Distribution, host specificity, and the potential for cryptic speciation in hoverfly Microdon myrmicae (Diptera: Syrphidae), a social parasite of Myrmica ants," Ecological Entomology, vol. 36, no. 2, pp. 135143, 2011.

[76] A. G. Radchenko and G. W. Elmes, Myrmica Ants (Hymenoptera: Formicidae) of the Old World, Natura Optima dux Foundation, Warszawa, Poland, 2010.

[77] W. Czechowski, A. Radchenko, and W. Czechowska, The Ants (Hymenoptera: Formicidae) of Poland, Museum and Institute of Zoology PAS, Warszawa, Poland, 2002.

[78] G. W. Elmes and J. Petal, "Queen number as an adaptable trait: evidence from wild populations of two red ant species (genus Myrmica)," Journal of Animal Ecology, vol. 59, no. 2, pp. 675-690, 1990.

[79] J. C. Wardlaw and G. W. Elmes, "Exceptional colony size in Myrmica species (Hymenoptera: Formicidae)," Entomologist, vol. 115, no. 3-4, pp. 191-196, 1996.
[80] M. V. Brian and A. F. Kelly, "Studies of caste differentiation in Myrmica rubra L. Maternal environment and the caste bias of larvae," Insectes Sociaux, vol. 14, no. 1, pp. 13-24, 1967.

[81] M. Witek, P. Skórka, E. B. Śliwińska et al., "Development of parasitic Maculinea teleius (Lepidoptera, Lycaenidae) larvae in laboratory nests of four myrmica ant host species," Insectes Sociaux, vol. 58, no. 3, pp. 403-411, 2011.

[82] P. Seppä and L. Walin, "Sociogenetic organization of the red ant Myrmica rubra," Behavioral Ecology and Sociobiology, vol. 38, no. 3, pp. 207-217, 1996.

[83] L. Sundstrom, "Sex allocation and colony maintenance in monogyne and polygyne colonies of Formica truncorum (Hymenoptera: Formicidae): the impact of kinship and mating structure," American Naturalist, vol. 146, no. 2, pp. 182-201, 1995.

[84] B. Baer and P. Schmid-Hempel, "Experimental variation in polyandry affects parasite loads and fitness in a bumble-bee," Nature, vol. 397, no. 6715, pp. 151-154, 1999.

[85] W. O. H. Hughes and J. J. Boomsma, "Genetic diversity and disease resistance in leaf-cutting ant societies," Evolution, vol. 58, no. 6, pp. 1251-1260, 2004.

[86] M. G. Gardner, K. Schönrogge, G. W. Elmes, and J. A. Thomas, "Increased genetic diversity as a defence against parasites is undermined by social parasites: Microdon mutabilis hoverflies infesting Formica lemani ant colonies," Proceedings of the Royal Society B, vol. 274, no. 1606, pp. 103-110, 2007.

[87] D. R. Nash and J. J. Boomsma, "Communication between hosts and social parasites," in Sociobiology of Communication-An Interdisciplinary Approach, P. d'Ettorre and D. P. Hughes, Eds., pp. 55-79, Oxford University Press, Oxford, UK, 2008.

[88] A. Lenoir, P. D'Ettorre, and C. Errard, "Chemical ecology and social parasitism in ants," Annual Review of Entomology, vol. 46, pp. 573-599, 2001.

[89] A. G. Bagneres, M. C. Lorenzi, G. Dusticier, S. Turillazzi, and J. L. Clement, "Chemical usurpation of a nest by paper wasp parasites," Science, vol. 272, no. 5263, pp. 889-892, 1996.

[90] T. L. Singer, "Roles of hydrocarbons in the recognition systems of insects," American Zoologist, vol. 38, no. 2, pp. 394-405, 1998.

[91] M. D. Greenfield, Signalers and Receivers: Mechanism and Evolution of Arthropod Communication, Oxford University Press, New York, NY, USA, 2002.

[92] W. H. Kirchner, "Acoustical communication in social insects," in Orientation and Communication in Arthropods, L. Lehrer, Ed., pp. 273-300, Birkenhauser, 1997.

[93] J. C. Nieh, "The honey bee shaking signal: function and design of a modulatory communication signal," Behavioral Ecology and Sociobiology, vol. 42, no. 1, pp. 23-36, 1998.

[94] J. C. Nieh and J. Tautz, "Behaviour-locked signal analysis reveals weak $200-300 \mathrm{~Hz}$ comb vibrations during the honeybee waggle dance," Journal of Experimental Biology, vol. 203, no. 10, pp. 1573-1579, 2000.

[95] S. S. Schneider, S. Painter-Kurt, and G. Degrandi-Hoffman, "The role of the vibration signal during queen competition in colonies of the honeybee, Apis mellifera," Animal Behaviour, vol. 61, no. 6, pp. 1173-1180, 2001.

[96] K. Donahoe, L. A. Lewis, and S. S. Schneider, "The role of the vibration signal in the house-hunting process of honey bee (Apis mellifera) swarms," Behavioral Ecology and Sociobiology, vol. 54, no. 6, pp. 593-600, 2003.

[97] H. Markl, "The evolution of stridulatory communication in ants," in Proceedings of the International Congress IUSSI, vol. 7, pp. 258-265, London, UK, 1973. 
[98] R. W. Taylor, "Nothomyrmecia macrops: a living-fossil ant rediscovered," Science, vol. 201, no. 4360, pp. 979-985, 1978.

[99] G. Grandi, Istituzioni di Entomologia Generale, Calderoni, Bologna, Italy, 1966.

[100] M. Giovannotti, "The stridulatory organ of five Ponerinae species. A sem study (Hymenoptera, Formicidae)," Fragmenta Entomologica, vol. 28, no. 1, pp. 157-165, 1996.

[101] G. Pavan, M. Priano, P. De Carli, A. Fanfani, and M. Giovannotti, "Stridulatory organ and ultrasonic emission in certain species of ponerine ants (genus: Ectatomma and Pachycondyla, hymenoptera, formicidae)," Bioacoustics, vol. 8, no. 3-4, pp. 209-221, 1997.

[102] D. A. Grasso, A. Mori, F. Le Moli, M. Giovannotti, and A. Fanfani, "The stridulatory organ of four Messor ant species (Hymenoptera, Formicidae)," Italian Journal of Zoology, vol. 65, no. 2, pp. 167-174, 1998.

[103] E. Ruiz, M. H. Martínez, M. D. Martínez, and J. M. Hernández, "Morphological study of the stridulatory organ in two species of Crematogaster genus: Crematogaster scutellaris (Olivier 1792) and Crematogaster auberti (Emery 1869) (Hymenoptera: Formicidae)," Annales de la Societe Entomologique de France, vol. 42, no. 1, pp. 99-105, 2006.

[104] F. Roces and B. Hölldobler, "Use of stridulation in foraging leaf-cutting ants: mechanical support during cutting or short-range recruitment signal?" Behavioral Ecology and Sociobiology, vol. 39, no. 5, pp. 293-299, 1996.

[105] R. Hickling and R. L. Brown, "Analysis of acoustic communication by ants," Journal of the Acoustical Society of America, vol. 108, no. 4, pp. 1920-1929, 2000.

[106] A. M. Fielde and G. H. Parker, "The reactions of ants to material vibrations," Proceedings of the Academy of Natural Sciences of Philadelphia, vol. 56, pp. 642-650, 1904.

[107] H. Autrum, "Uber Lautäußerungen und Schallwahrnehmung bei Arthropoden-I. Untersuchungen an Ameisen. Eine allgemeine Theorie der Schallwahrnehmung bei Arthropoden," Zeitschrift für Vergleichende Physiologie, vol. 23, no. 3, pp. 332-373, 1936.

[108] J. G. Menzel and J. Tautz, "Functional morphology of the subgenual organ of the carpenter ant," Tissue and Cell, vol. 26, no. 5, pp. 735-746, 1994.

[109] F. Roces and J. Tautz, "Ants are deaf," Journal of the Acoustical Society of America, vol. 109, no. 6, pp. 3080-3082, 2001.

[110] R. Hickling and R. L. Brown, "Response to "ants are deaf"," Journal of the Acoustical Society of America, vol. 109, no. 6, p. 3083, 2001.

[111] H. Markl, B. Hölldobler, and T. Hölldobler, "Mating behavior in Novomessor (Formicidae, Hymenoptera). Vibration signals," Behavioural Ecology and Sociobiology, vol. 4, pp. 183216, 1977.

[112] H. Markl, " Manipulation, modulation, information, cognition: some of the riddles of communication," in Experimental Behavioural Ecology and Socio Biology, B. Hölldobler and M. Lindauer, Eds., pp. 163-185, Fischer, Stuttgart, Germany, 1985.

[113] C. Baroni-Urbani, M. W. Buser, and E. Schilliger, "Substrate vibration during recruitment in ant social organization," Insectes Sociaux, vol. 35, no. 3, pp. 241-250, 1988.

[114] F. Roces, J. Tautz, and B. Holldobler, "Stridulation in leafcutting ants. Short-range recruitment through plant-borne vibrations," Naturwissenschaften, vol. 80, no. 11, pp. 521-524, 1993.

[115] A. B. Ware, "Factors eliciting stridulation by the ponerine ant Streblognathus aethiopicus Smith (Hymenoptera: Formicidae)," African Entomology, vol. 2, no. 1, pp. 31-36, 1994.
[116] B. Hölldobler, "The chemistry of social regulation: multicomponent signals in ant societies," Proceedings of the $\mathrm{Na}$ tional Academy of Sciences of the United States of America, vol. 92, no. 1, pp. 19-22, 1995.

[117] F. Roces and B. Holldobler, "Vibrational communication between hitchhikers and foragers in leaf-cutting ants (Atta cephalotes)," Behavioral Ecology and Sociobiology, vol. 37, no. 5, pp. 297-302, 1995.

[118] J. C. Santos, A. P. Korndörfer, and K. Del-Claro, "Defensive behavior of the weaver ant Camponotus (Myrmobrachys) senex (Formicidae: Formicinae): drumming and mimicry," Sociobiology, vol. 46, no. 2, pp. 279-288, 2005.

[119] B. Hölldobler and F. Roces, "The behavioural ecology of stridulatory communication in leafcutting ants," in Model systems in Behavioural Ecology: Integrating Empirical, Theoretical and Conceptual Approaches, L. Dugatkin, Ed., pp. 92109, Princeton University Press, Princeton, NJ, USA, 2000.

[120] R. J. Stuart and P. D. Bell, "Stridulation by workers of the ant, Leptothorax Muscorum (Nylander) (Hymenoptera, Formicidae)," Psyche, vol. 87, pp. 199-210, 1980.

[121] R.D. Zhantiev and A.V. Sulkanov, "Sounds of ants of the genus Myrmica," Zoolicheskii Zhurnal, vol. 56, pp. 12551258, 1977.

[122] H. Markl, "Communication by stridulatory signals in leaf cutting ants-II. Production and characteristics of the signals," Zeitschrift für Vergleichende Physiologie, vol. 60, no. 2, pp. 103-150, 1968.

[123] J. A. Thomas, K. Schönrogge, S. Bonelli, F. Barbero, and E. Balletto, "Corruption of ant acoustical signals by mimetic social parasites-Maculinea butterflies achieve elevated status in host societies by mimicking the acoustics of queen ants," Communicative \& Integrative Biology, vol. 3, no. 2, pp. 169-171, 2010.

[124] F. Barbero, S. Bonelli, J. A. Thomas, E. Balletto, and K. Schönrogge, "Acoustical mimicry in a predatory social parasite of ants," Journal of Experimental Biology, vol. 212, no. 24, pp. 4084-4090, 2009.

[125] J. Settele, F. Barbero, M. Musche, J. A. Thomas, and K. Schönrogge, "Singing the blues: from experimental biology to conservation application," Journal of Experimental Biology, vol. 214, no. 9, pp. 1407-1410, 2011.

[126] J. C. Downey and A. C. Allyn, "Sounds produced in pupae of Lycaenidae," Bulletin of the Allyn Museum of Entomology, vol. 48, pp. 1-14, 1978.

[127] H. Prell, "Uber zirpende schmetterlingspupen," Biologisches Centralblatt, vol. 33, pp. 496-501, 1913.

[128] J. C. Downey, "Sound production in pupae of Lycaenidae," Journal of the Lepidopterists' Society, vol. 20, pp. 129-155, 1966.

[129] J. C. Downey and A. C. Allyn, "Butterfly ultrastructure: 1. Sound production and associated abdominal structures in pupae of Lycaenidae and Riodinidae," Bulletin of the Allyn Museum of Entomology, vol. 14, pp. 1-39, 1973.

[130] K. G. Schurian and K. Fiedler, "Einfache Methoden zur Schwallwahrnehmung bei Blaulings-Larven (Lepidoptera: Lycaenidae)," Entomologische Zeitschrift, vol. 101, pp. 393412, 1991.

[131] M. A. Travassos and N. E. Pierce, "Acoustics, context and function of vibrational signalling in a butterfly-ant mutualism," Animal Behaviour, vol. 60, no. 1, pp. 13-26, 2000.

[132] P. J. DeVries, R. B. Cocroft, and J. Thomas, "Comparison of acoustical signals in Maculinea butterfly caterpillars and their obligate host Myrmica ants," Biological Journal of the Linnean Society, vol. 49, no. 3, pp. 229-238, 1993. 
[133] A. Di Giulio, E. Maurizi, M. Sala, S. Bonelli, F. Barbero, and E. Balletto, "Acoustic communication in the myrmecophilous beetle Paussus favieri," in Proceedings of the Meeting of the French Section of the International Union for the Study of Social Insects (IUSSI ), Banyuls-sur-Mer, France, April 2011.

[134] J. Tautz, "Reception of medium vibration by thoracal hairs of caterpillars of Barathra brassicae L. (Lepidoptera, Noctuidae)-I. Mechanical properties of the receptor hairs," Journal of Comparative Physiology A, vol. 118, no. 1, pp. 1331, 1977.

[135] J. Tautz, "Reception of medium vibration by thoracal hairs of caterpillars of Barathra brassicae L. (Lepidoptera, Noctuidae)-II. Response characteristics of the sensory cell," Journal of Comparative Physiology A, vol. 125, no. 1, pp. 6777, 1978. 

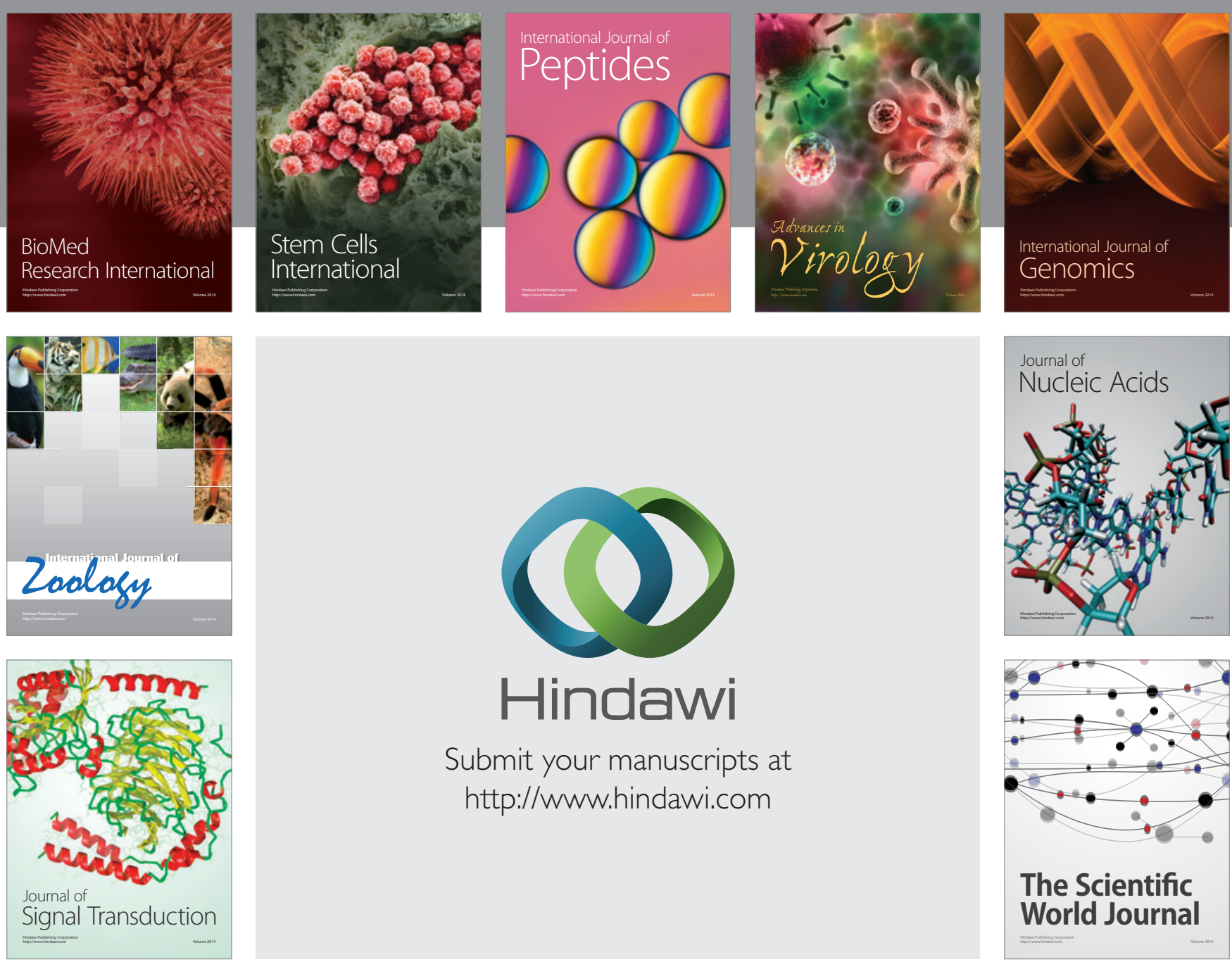

Submit your manuscripts at

http://www.hindawi.com
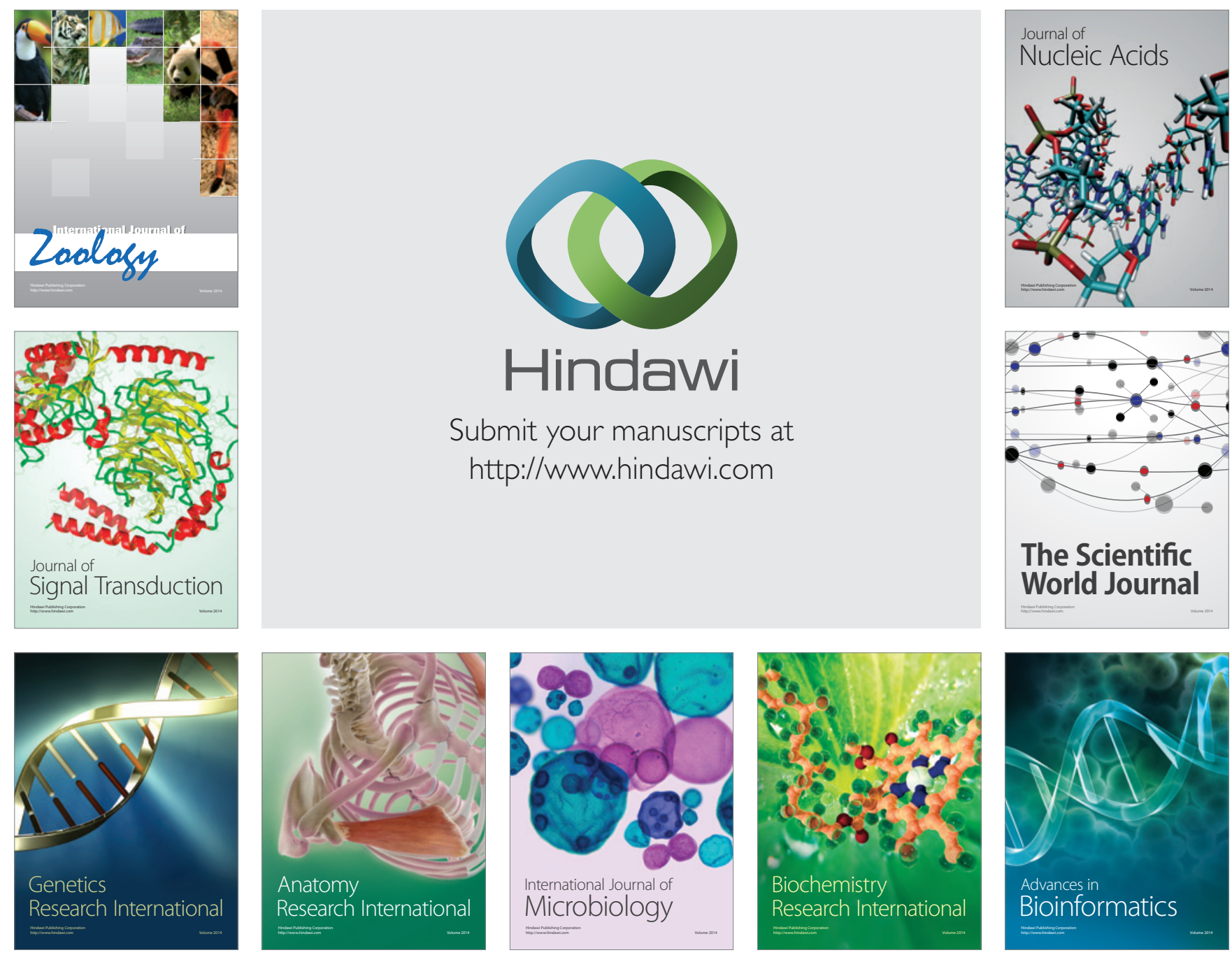

The Scientific World Journal
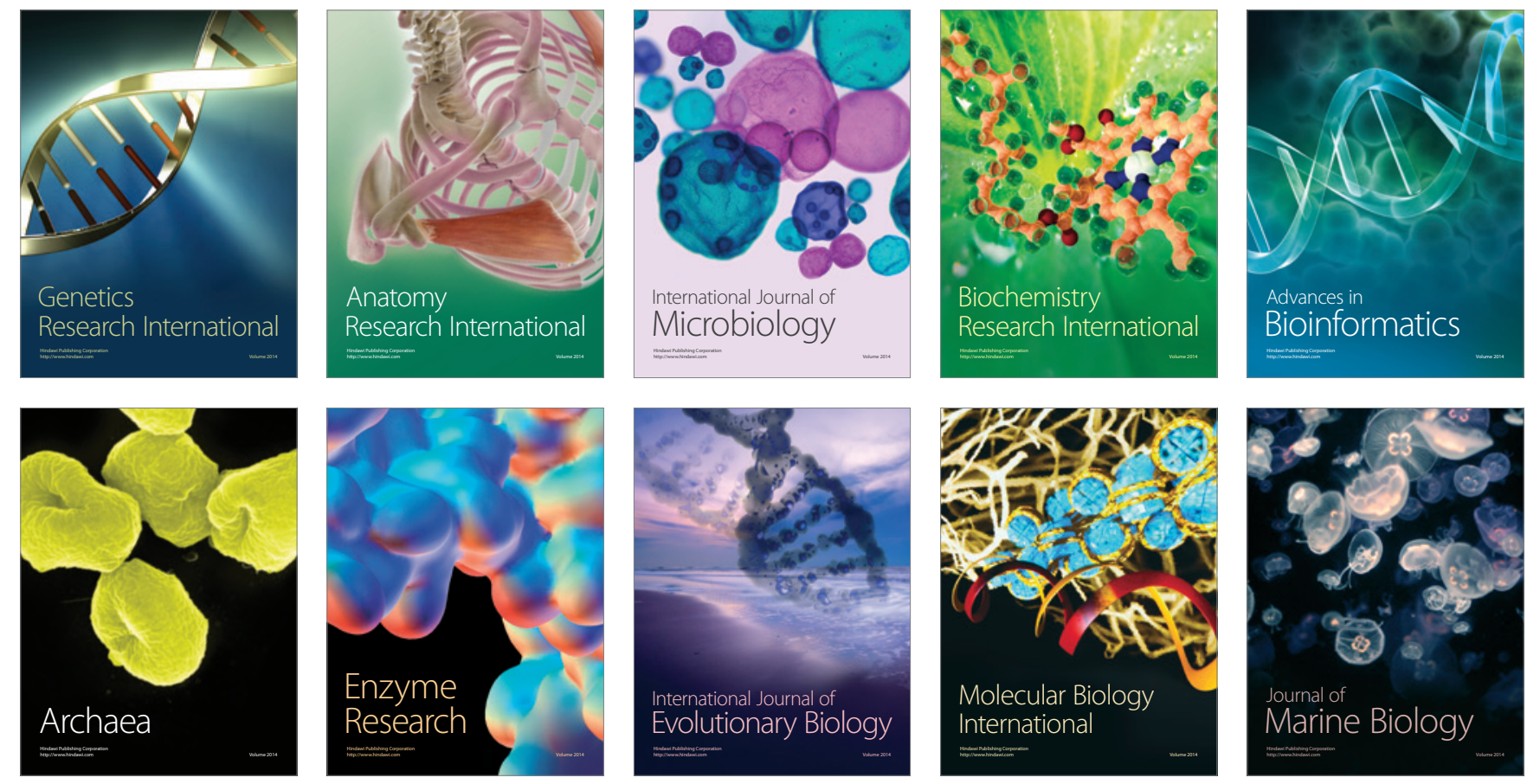